$$
\begin{array}{r}
\text { THE SO } \\
\text { OF THE MOC } \\
\text { OF a widespread amazonian }
\end{array}
$$




\section{THE SONS OF THE MOON: \\ THE AMAHUACA VERSION OF A WIDESPREAD AMAZONIAN MYTH}

\section{ROB E R T L. C A R N E I R O}




\begin{abstract}
In a previous publication, I presented the Kuikuru version of an important myth from the Upper Xingú which I called "To the Village of the Jaguars." A version of this myth is widely distributed among Amazonian groups, including the Amahuaca, a Panoan-speaking group of eastern Peru and western Brazil. The Amahuaca version is presented here as I recorded it among them in 1960 and 1961. After presenting the text of the myth, I discuss specific similarities and differences between the Amahuaca and Kuikuru versions of it.
\end{abstract}

Key words: Amazonian myth, Amahuaca Indians, Kuikuru Indians.

\title{
Resumo
}

Em uma publicação anterior, apresentei a versão Kuikuru de um importante mito do Alto Xingú, que eu chamei de "Para a Aldeia das Onças". Uma versão desse mito encontra-se largamente distribuída entre grupos amazônicos, incluindo os Amahuaca, um grupo falante Pano do leste peruano e do oeste brasileiro. A versão Amahuaca é apresentada aqui assim como foi registrada por mim entre 1960 e 1961. Depois de apresentar o texto do mito, eu discuto similaridades e diferenças específicas entre as versões Amahuaca e Kuikuru do mito.

Palavras-chave: Mito Amazônico, índios Amahuaca, índios Kuikuru.

\section{Resumen}

En una publicación anterior, yo he presentado una versión de un importante mito del Alto Xingú, que yo he llamado "Hasta la Aldea de los Jaguares". Una versión de este mito se la encuentra largamente distribuida entre los grupos amazónicos, incluyendo los Amahuaca, un grupo hablante de Pano del este peruano y del oeste brasileño. La versión Amahuaca es presentada aquí así como la oí en 1960 y 1961. Después de presentar el texto del mito, yo discuto similitudes y diferencias específicas entre las versiones Amahuaca y Kuikuru del mito.

Palavras-clave: Mito Amazónico, índios Amahuaca, índios Kuikuru. 


\section{INTRODUCTION}

As a graduate student I used to disdain the study of mythology. To me it seemed trivial, and at best peripheral to the solid substance of anthropology. But over the years, especially as I began to do ethnographic field work and to collect myths myself, my attitude toward mythology changed. For one thing, I became more fully aware of and began to admire - the touches of imagination so much in evidence in the myths of primitive peoples.

Another aspect of myths that increasingly impressed me was their role in accounting for the things and events of the world, both terrestrial and celestial. Many myths seemed expressly designed to explain features that primitive peoples were familiar with, but could not possibly understand. How, for example, could an Amazonian Indian, utterly ignorant of plate tectonics, know the causes of an earthquake? Myths provided answers to questions such as this, and to countless others: Why do we have an alternation of day and night? What produces thunder and lightning? Why do eclipses occur? And why do the Sun, the Moon and the stars sit up in the heavens and look down upon us?

At a rudimentary stage of culture, it was impossible for primitive peoples to formulate anything like a scientifically accurate explanation of many natural phenomena. Still, human curiosity has always been strong and insistent. And so human beings devised stories purporting to account for how these things came to be. Moreover, in that credulous age these stories were read- ily believed. As a result, today we have for our perusal an enormous corpus of origin myths.

Of course, there is a lot more to mythology than simply providing answers to questions. Myths are stories spun out of the human imagination ... narratives showing great and unending creativity. And indeed even, oftentimes, revealing flashes of literary merit.

Moreover, it is not just the content of myths that attracts our interest. It is also their structure, for myths have an identifiable architecture. They consist of segments - building blocks - which are assembled together. These building blocks - the so-called myth motifs - are joined to form a coherent whole. Still, these segments are separable. They can be disassembled and reassembled in different ways. When we examine several versions of what we regard as basically the same myth we see how the component elements can be rearranged in various ways. And the segments themselves can be altered: they can be elaborated or truncated. Or they can be left out altogether. At the same time, entirely new elements may be introduced and joined with older ones to alter or enhance the myth. The basic myth may still be recognizable as an entity, but the different combinations of its elements may impart to the new version of it a distinctly different character.

I mentioned that individual elements of a myth may be elaborated. What started out as a simple episode in one version of the myth may be lengthened, complicated, and embellished in another version. Here is where we 
see the mythmaker at work. The gifted storyteller is not likely to feel a sense of obligation to a myth as he originally heard it. The urge to embellish it may be too strong to resist. He sees an opportunity to brighten up the myth and he takes it.

Let me offer a concrete example of this process. The myth I call "To the Village of the Jaguars," which I collected among the Kuikuru in 1975 (Carneiro 1989) is a case in point. More than half the pages of the printed version of this myth consist of footnotes 170 of them in all. And each footnote represents a variant, small or large, of other versions of this myth that have been recorded. Each variant is a case where the re-teller of the myth, in one Upper Xingú village or another, found himself giving a slight creative twist to the myth as he recounted it.

Now, if we go back to the very beginning of things, there is no question that myth had to be invented. Whatever subsequent listeners to the myth may have thought about it, the person who first told it had to know it was a fabrication. He may have reasoned that if he made the story vivid, detailed, and persuasive enough, people around him would tend to believe it.

Yet another aspect of myths make them useful to the anthropologist. By comparing myths gathered over a large area like Amazonia it may be possible to see historical connections among societies spread over a large region. Entire myths, or portions of them, may be retained by societies which were once neighbors but have moved apart, revealing a former closeness now broken. Alternatively, two distant tribes may come to have the same myth through diffusion. Historical reconstruction may thus be aided by the study of mythology.

The Amahuaca myth to be presented here is one which I find of particular interest. It is by no means unique to the Amahuaca or the Kuikuru, who share certain core features of it. Indeed, the myth is found over much of Amazonia. But while the Amahuaca and Kuikuru versions of it have several elements in common, there are also distinct differences between them. The fact that certain common elements of the two occur far and wide in Amazonia suggests that the myth has a respectable antiquity. At the same time, it indicates that other parts of the myth are easily detached from its core. Or perhaps they are simply more susceptible to decay. So far as I know, though, the myth does not occur outside of greater Amazonia. It would appear, then, that the myth did not take shape until well after Indians had moved into Amazonia.

The particular version of the myth given below was told to me by Amahuaca informants in 1960 and 1961. The Amahuca are a Panoan-speaking group inhabiting parts of the Peruvian Montaña. The myth does not have a common name, although Alfred Métraux, who first recognized it as distinctive, called it a twin myth in the title of his article about them (Métraux 1946). While twins do occur in the myth-the Sun and the Moon, for example-this is a relatively minor element of the 
myth. For reasons that will soon become apparent, a more fitting designation for the Amahuaca version is "The Sons of the Moon." Some years ago I published the Kuikuru version of this myth, calling it "To the Village of the Jaguars (Carneiro 1989), and this name could also fittingly be applied to the Amahuaca version of it. While the two myths differ widely in a number of respects, at certain points they virtually coincide. In fact, these coincidences in the Amahuaca and Kuikuru versions are also found in almost all recorded versions of it throughout Amazonia.

The core element to which I refer is a journey undertaken by a woman (or sometimes several women) which sees her winding up in the village of the jaguars. Her arrival there is followed by a series of untoward incidents behind which is the Mother Jaguar.

What can we say about the origin of this myth? The ethnologist Roque Laraia (1967:17-19) supposed the myth to be restricted to Tupían-speaking groups, but such is not the case. Métraux (1946) noted its presence among the Cuna, Carib, Wapishana, Warao, Amuesha, Boro, Witoto, Záparo, Yurucaré, and Jívaro (Shuar)-none of them Tupían. To this list I can add not only the Amahuaca and the Kuikuru, but also other groups of the Upper Xingú, which include Arawak and Carib speakers, as well as Tupíans. And a thorough search of the literature would, no doubt, turn up still other Amazonian tribes having this myth. At this point, then, all we can say about its origin is that it is too widely distributed to permit even an educated guess as to where it began.

Without further ado, I present below "The Sons of the Moon," the Amahuaca version of this widespread myth, one of the most distinctive in all of Amazonia 1.

\section{THE SONS OF THE MOON}

Far back in the mythological past, a woman named Wintá, who lived in a village deep in the rain forest, entertained a lover at night. Since he came to her hammock only after dark, and would not give his name, she had no idea who he was. But she was very curious, and in order to determine his identity, one night, while she waited for him to come to her, she smeared her hands with the juice of the huito fruit (Genipa americana). Then, when he lay with her in her hammock, she caressed his face, rubbing the huito juice on his cheeks, marking him indelibly. Suspecting nothing, he made love to her and then left.

The next day Wintá had a masato (manioc beer) party to which she invited everyone in the village. In this way she immediately saw whose face was marked with huito juice and at last discovered who her mysterious lover was. And to her horror, she found it was her own brother, Oxï. "You are like a dog, not a human being," she berated him. Greatly ashamed at having been exposed, Oxï left the village, telling no one where he was going.

Not long afterward, Wintá discovered she was pregnant with twins ${ }^{2}$. One of 
the two fetuses (both of whom were male) wanted very much to see his father, and asked his mother to undertake a journey to find him. At first she refused, but finally she gave in to the request and left the village in search of her incestuous brother, Oxï.

As Wintá was walking along the trail through the forest, one of her fetuses became hungry for a certain kind of fruit and asked his mother to get him some. She agreed to pick the fruit but would not eat it, so that the fetus remained hungry. A little later he said to her, "There's another fruit tree, get some for me." She did so and this time she ate it. She did this twice more, but the next time she acceded to her fetus' request and picked some fruit she was stung by a wasp. Angered by this, she reproached her fetus: "Why are you always asking for fruit?" and slapped her abdomen, stunning the fetus so he could no longer speak.

Shortly thereafter, Wintá came to a fork in the trail. A macaw tail feather had been stuck in the right-hand trail by Oxï so that his fetus son would know which way he had gone and could direct his mother along the correct path. The fetus knew what the macaw tail feather meant, but having been slapped senseless by his mother, he was unable to tell her which way to go. So, unaware of the meaning of the feather, Wintá took the wrong path.

Walking along the trail, Wintá passed a large banana grove, and then a corn field, and finally she came to the village of the jaguars. The jaguars were out hunting at the time, and only the old
Mother Jaguar was home. She asked Wintá where she had come from and what she was looking for, and Wintá replied, "I've come with my two fetuses to find their father, but I must have taken the wrong fork in the trail."

"Don't go," the Mother Jaguar pleaded, "stay here and keep me company." Wintá was afraid that she and her fetus sons would be eaten by the jaguars and demurred. However, the Mother Jaguar reassured her. "Don't be afraid," she said, "my children won't eat you." So Wintá decided to stay.

After a while, the jaguars returned home. There were many of them. In order to protect Wintá from them, the Mother Jaguar had her climb up to the rafters and hide there ${ }^{3}$. From this vantage point she could see the jaguars, back from the day's hunt, laying down collared peccaries, white-lipped peccaries, monkeys, curassows, and other animals they had killed.

Catching Wintá's scent, the jaguars asked their mother what animal was around the house. "Oh, it's only Wintá, who's come to live with me," she replied. And then she called for Wintá to come down from the rafters. But as Wintá was descending, the jaguars pounced on her, killed her, and ate her. Among the little that was left of her when they had finished were two eggs, the size of a curassow's. Disoriented, the fetuses inside the eggs cried, "Here we are, mother!" The Mother Jaguar told the jaguars to put the eggs inside a big ball of cotton, and in about a week the eggs hatched. Four little curassows came out, crying "hwi, hwi," like baby 
curassows do $\mathrm{d}^{4}$. Though born as birds, the little curassows soon turned into boys and grew rapidly. Unaware of what had happened to their mother, they remained with the Mother Jaguar and were raised by her.

One day, when the boys were the size of 4- or 5-year-olds, some deerflies began to bother the Mother Jaguar, and she asked the boys to kill them. To do so, each boy made a tiny little bow and arrow. The Mother Jaguar asked them to shoot a deerfly that had landed on her hip. The first boy shot, but hit the Mother Jaguar instead. It hurt, and she cried out, "Ah! Ah! Ah!" Then the second boy shot and his arrow hit her in the back, killing her ${ }^{5}$.

Having killed the Mother Jaguar, the boys asked themselves, "What shall we do with her?" They decided to cut a piece of skin from her loins, carry it to where the Mother Jaguar had been gathering firewood, and stake it to the ground to dry. The boys then called on the piece of skin, "Mama!" as if they were her sons, in order to fool her. The piece of skin answered, "Huu," tore up the stakes, and turned into an evil spirit (yushi) ${ }^{6}$.

The boys then decided to cook the Mother Jaguar and trick her sons into eating her flesh. After all, they reasoned, since the jaguars had eaten the boys' mother, it was only fair that they should be made to eat their own mother. So they cut the Mother Jaguar's body into pieces and put them in a pot, with the head at the very bottom. On top of her flesh they put pieces of peccary meat to fool the jaguars into thinking it was just an ordinary pot filled with meat they had obtained in the hunt. After arranging the pot in this way, they put it on the fire to cook.

Around three o'clock in the afternoon the jaguars returned home crying, "huu, huu, huu." The boys wondered what to do next. One boy said, "Let's turn ourselves into birds," and they all did so, flying to the top of a nearby tree to see what would happen. The jaguars wondered where their mother was and called out, "Mama! Mama!" Off along the trail, the Mother Jaguar's stakeddown skin answered, "Huu."7

The jaguars thought their mother must be out collecting firewood with the boys so they said, "Let's eat." They began taking the meat out of the pot, each jaguar grabbing a piece, until the last jaguar reached down to the bottom of the pot and pulled out the last remaining portion - their mother's head. "Ay, damn it!" he shouted. "The boys must have killed our mother! Let's find them and kill them!"

They picked up a blowgun ${ }^{8}$ to shoot the boys, who were now birds perched on a tree. But the boys took flight and flew to the top of a tall shihuahuaco tree (Dipteryx sp.). Walking along the ground, the jaguars were able to follow the little birds but could not kill them. Flying from tree to tree, the birds finally lost the jaguars. When at last they felt safe, they came down to the ground and turned back into boys.

As they walked along the trail, they came upon a man making a dugout canoe $^{9}$. The man was really a tapir-tapirs in those days having human form. The tapir owned a grove of guava trees 
nearby, and the boys, who were hungry by this time, asked if they could have some fruit. The tapir told them to go ahead and take some, so the four boys climbed one of the guava trees and began eating some of the fruit. The tapir called up to them that he wanted some too, and asked the boys to toss down a couple of ripe fruit. Instead, the boys took a green guava and threw it at the tapir, hitting him in the back. Again the tapir asked for a ripe guava fruit and added, "Don't hit me with it." But the boys threw down another green one anyway, and once more hit the tapir on the back. Angered by this, the tapir kicked the guava tree, and it became a giant silk-cotton tree (Ceiba pentandra).

The silk-cotton tree was so tall that the boys could not climb down, and were forced to remain in its branches for four years. With no food available to them, the boys were forced to eat leaves to survive. After a long time they asked themselves, "How are we going to get down?" "Let's turn ourselves into chaopara ants," one of them suggested, and they did so. "Who will climb down first?" they asked. "I will," one of them replied, and biting the midrib of a leaf and holding on tight, he jumped out of the tree and floated down to earth.

Once he had reached the ground, he heard the others call to him, "How is it down there?" "Good! Come on down!" he replied. So each of the other ants in turn bit the midrib of a leaf and came fluttering down. Two of them made it to the ground, but the third was left in the tree when his leaf got stuck in the crotch of a lower limb. The others called to him to come down, but he couldn't. With a long stick they poked the leaf free of the tree, and it floated down to earth. Once all four were on the ground, the ants turned themselves back into boys. Since four years had elapsed since they had been stranded in the tree, the boys were now much bigger.

However, they had not forgotten how they'd come to be stuck up in the tree all this time, and so they said, "Let's kill the tapir!" But where was he? A long time had passed since they had last seen him. To find out, one of the boys climbed another tree and reported he could see the tapir in the distance, walking along the trail. "Let's follow him," they said.

As they walked, the boys came across a large huito tree which had grown up from seeds excreted by the tapir. "How long ago did the tapir go by?" they asked the huito tree. "Four years," was the reply. Continuing to walk, they found another huito tree, slightly smaller, which had also grown from seeds excreted by the tapir. When they asked this tree how long it had been since the tapir passed, it answered, "Three years." The boys kept on walking and asked the next huito tree, which was smaller yet, how long ago the tapir had passed, and it answered, "Two years."

Next they came across a chest-high huito tree, which told them the tapir has been there the year before. A kneehigh huito told them nine months, and then an ankle-high huito said eight months. The next tree, which was four inches high, said the tapir had been by 
seven months earlier. Then they found some dry tapir dung with huito seeds just sprouting from it and were told the tapir had gone by six months before. "We're getting closer," the boys said, and kept walking.

Now they found some dry manure which the tapir had deposited five months earlier, and then some fresh manure four months old. Continuing to walk, they found successively fresher manure, three, two, and one month old. Then came manure one week old, and then manure only half an hour old. Finally, lying fast asleep and snoring by the side of the trail, they came upon the tapir himself ${ }^{10}$.

"How are we going to kill him?" the boys asked themselves. One of them had an idea. "I'll turn myself in an $i$ [a tiny stinging ant called 'chupa culo' in jungle Spanish], and climb inside the tapir through his anus. Then, when I get to his heart, I'll sting it and he will die. As he's dying, he will give a kick, and that will be your signal to get me out."

And it happened just the way the boy had said. When the dying tapir gave a kick, the other boys took a machete, cut open its belly, and pulled out their brother.

The boys then decided to eat the dead tapir. "How shall we cook him?" they asked, and finally decided to boil him. "I'll make a pot," one of the boys volunteered. "I'll make a fire," the second one said. The third one cut the tapir into small pieces, while the fourth one went to get manioc to eat with the meat. Once the tapir was butchered, it was put into the pot along with some manioc, and the pot was placed on the fire to boil.

At this point, the pot spoke up, saying, "When I cry out, throw me into the stream," and the boys agreed to do so. As the water came to a boil, the pot, being very hot, cried out as it said it would, whereupon the boys took the meat out and threw the pot into the water. As soon as the pot hit the water, a lot of people came out of it, looking very red because they had been so hot. These were all people the tapir had killed in the past.

The meat was not yet done, though, so the boys made another pot and placed the meat inside it to cook some more. Again the pot cried out when it was too hot, and again the boys took out the meat and threw the pot into the water. And once more people came out of it. This time the meat was done. One of the boys cut some leaves and served out a portion of tapir meat and manioc on each one. The boys did not finish the meat ${ }^{11}$. When they had eaten all they wanted, they put the rest of the meat aside and left.

The boys started walking along the trail again until at last they came to a very large lake. Near the shore of the lake they saw a huge caiman and called out to it. "What do you want?" the caiman asked. "We want to get across the lake. Bring over your canoe." The caiman told them he had no canoe, but would be willing to ferry them across on his back. The boys agreed, and when they had all 
climbed on his back, the caiman set off across the lake.

As the caiman swam through the water, he broke wind loudly. "Does it smell?" asked one of the boys. "No," said another. They asked the caiman if he was breaking wind, but the caiman denied it. Again, though, the caiman broke wind. "Does it smell?" the boy asked once more, and the answer was again, "No." Then another boy said, "The caiman will break wind twice more. When he does so for the fourth time, it will smell, and this will be the signal that he is about to eat us."

When the caiman reached the middle of the lake, he broked wind for the third time. "What should we do when the caiman breaks wind again?" the boys asked, and decided to save themselves by turning into birds. Each in turn then named the bird he was going to become, the last one saying, "I'll become a tinamou."

When the caiman broke wind for the fourth time, it was a tremendous one. "Does it smell?" the boys asked. "Yes!", was the answer, and immediately the four of them turned themselves into birds and flew away. Three of the boys were able to reach the opposite shore, but the fourth - the one who had become a tinamou, a weak-flying birdcould not make it and fell into the lake. The caiman swam to the spot where the bird had gone down, swallowed it in one gulp, and then submerged.

On the shore, the three surviving boys worried about the fate of their brother. They asked a sloth for a huge pot with which to drain the lake so they could find the caiman and kill it. The sloth obliged, and the boys filled an enormous jar with lake water. But it was not big enough to empty the entire lake. They then asked a parrot for a spear ${ }^{12}$, which they threw into the middle of the lake, and this time succeeded in emptying the lake.

Once the lake bed was dry, the boys walked along the bottom to look for the caiman. Plenty of other caimans were there too, but they went to the spot where they had seen the huge caiman submerge after it had swallowed their brother. There, under a great pile of water-logged tree trunks, they found the caiman and killed it with clubs and axes. They called to the brother who had been eaten by the caiman, and he answered, "I'm not dead, I'm still alive. I'm inside the caiman's stomach." First they reproached him for being so foolish as to turn himself in a weakflying tinamou, but then they cut open the caiman and took him out. He was still a tinamou, but immediately turned himself human again.

One of the brothers decided to remain by the edge of the lake as a takoa bird. The other three, however, set off on a trail, stopping along the way to make bow staves, bowstrings, and arrows. Once their bows and arrows were ready, one of the boys said, "Let's shoot arrows into the sky." The first boy shot his arrow, but it failed to reach the sky. The second boy did not reach the sky either. The third boy said, "I'll shoot harder and I'll hit the sky," and he did, his arrow sticking into the underside of the sky, lodging there. 
The other boys continued to shoot, each hitting the butt end of the previous arrow, until they had formed a chain of arrows reaching all the way from the sky to the ground ${ }^{13}$.

They then called waiwashi, the squirrel, and asked him to climb up the arrow chain until he reached the sky and to throw down a ladder from there. The squirrel climbed as high as he could, but could not make it to the very top. So then the boys turned to kurukapa, a smaller species of squirrel, and asked him to see if he could reach the sky. "When you get to the top," they said, "throw down some yellow earth and some red earth. This will be a signal that you've arrived, so we can expect the ladder to come down next."

When the little squirrel got to the sky, he threw down some yellow earth and some red earth. Shortly thereafter, the ladder, which was shiny, came down to earth too. Up the ladder the three boys climbed until they reached the sky. But then some dangerous animals began to climb up after them, including fer-delances, bushmasters, and other poisonous snakes, as well as yushi, that is, evil spirits. By the time the first of these animals neared the top, though, so many of them were on the ladder that the strain proved too great and it broke, and all the bad animals came tumbling down to earth and were killed.

Up in the sky, the boys asked each other, "What are you going to become?" One of them said, "I'll become the star Wishitoki, and you?" "I'll become the star Wishitowi." The third brother decided to become the constellation Kapïkuni." ${ }^{14}$
None of them, of course became the Moon, for the Moon was already in the sky. Indeed, it turned out that the Moon was none other than their father, Oxi, whom they had originally set out to find. And the markings visible on the Moon's surface were the indelible caresses left on his face by his sister, Wintá, during their laste fateful embrace.

\section{COMPARING THE AMAHUACA AND KUIKURU VERSIONS OF THE MYTH}

Having presented the Amahuaca version of this myth, it may be appropriate to compare it in certain details to the Kuikuru version, given fully in Carneiro (1989). To begin with, in the Amahuaca version, the woman sets out with no intention of proceeding to the village of the jaguars. Her only goal is to find her brother, the father of her fetuses. Only by taking the wrong fork in the trail does she inadvertently find herself in the jaguar's village.

In the Kuikuru version, arrival at this village is quite a different matter. According to this version, a hunter finds himself surrounded by a band of jaguars who threaten to eat him. To get out of his predicament, he promises the jaguar chief to send him his two beautiful daughters as wives. However, once home, finding that he cannot bring himself to send his own daughters, he carves six women out of wood, brings them to life, and as surrogates for his real daughters, sends them to the jaguar chief.

After a series of misadventures in which four of the six girls are killed, the two surviving ones make it to the jaguars' village. (Again, one of them 
taking the wrong fork in the trail.) In both the Amahuaca and Kuikuru versions, the Mother Jaguar - who appears as a malevolent figure in just about every recorded version of the myth - receives the girls but betrays one of them so that she dies. However, she gives birth posthumously to twins, who eventually, learning the truth, kill the Mother Jaguar.

Another important difference in the two versions is that in the Amahuaca one the woman arrives in the jaguar's village already pregnant. In the Kuikuru version, though, she has been sent there by her father to become the bride of the jaguar chief and soon becomes pregnant by him.

In both versions, twins are born posthumously to the woman. In the Kuikuru version they are raised by their aunt - their mother's sister - but in neither case do the boys know the full story of what has transpired. Specifically, in neither case are the twins aware that the Mother Jaguar was responsible for their mother's death. In both versions, though, the boys kill the Mother Jaguar, cut up her body, and trick the jaguars into eating the pieces, discovering their mistake only when they find their mother's head at the bottom of the pot.

Outraged at what has occurred, the jaguars are intent on avenging themselves on the boys. Among the Kuikuru, the boys are, however, protected by the fact that their father is the jaguar chief. But in the Amahuaca version, the twins (who somehow have become four) flee and make good their escape. After a series of adventures, both sets of boys - Kuikuru and Amahuaca wind up in the sky. The Kuikuru twins become the Sun and the Moon, while the Amahuaca boys - as stars or constellations - end up in the sky, along with their father, the Moon.

One feature of both versions - which allows the myth to be elaborated at considerable length - is the fact that they contain numerous incidents or episodes that are either inessential to the main plot, or distinctly subordinate to it. These incidents occur at either or both ends of the narrative - that is, before or after the happenings in the jaguar village. In the Kuikuru case, it is a series of misadventures that befall the six wooden women on their way to the village of the jaguars that is elaborated. In the Amahuaca version, the adventures involve the four sons of the Moon after they've escaped from the jaguars.

Enough having been said about the similarities and differences between the two versions of the myth, I will make just one more observation. The great storyteller Rudyard Kipling coined the term "Just so Story" for a myth or folk tale that accounted for some characteristic or peculiarity of an animal or object. "How the Leopard Got His Spots" is a well known example. Two "Just so Stories" regarding the Moon occur in the two versions of this myth we have just cited. The Amahuaca version accounts for the marks visible on the Moon's surface, while the Upper Xingú version accounts for the Moon's size in the following way:

As they look down on the earth from their place in the sky, the Sun and the Moon are clearly of different sizes. Yet in the Upper Xingú myth, which tells of their origin, the Sun and the Moon are twins, born of the same mother, at the 
same time, and, initially of the same size. How, then, did they become so different in size? The answer is simple. Their mother having died at the time of their birth, the Sun and the Moon were raised by their aunt. Now it so happened that their aunt had one large breast and one small one. And the Sun nursed at her large breast, while the Moon nursed at her small one. By this one deft touch, then, the myth is able to account for a celestial phenomenon which took astronomers centuries to resolve!

\section{NOTAS}

${ }^{1}$ This myth is known to the neighboring Shipibo and Conibo as well, and in one version of it, told to me by an Amahuaca who had lived for a time with the Conibo, the occurrence of a blowgun - a weapon not known to the Amahuca but present among the Conibo - suggests that what the informant told me may have been (in part at least) the Conibo version of the myth.

${ }^{2}$ In one version of the myth, Wintá discovers she is pregnant before giving the party.

${ }^{3}$ According to one version, Wintá climbed up a tree to hide.

${ }^{4}$ Somehow, in a manner not explained by the informant, the original two eggs had become four. So from here on, the twin myth - so common in Amazonia - ceases to be such.

${ }^{5}$ In the version of the myth I recorded, there is no indication-as there is in some other versions - that the boys had discovered the Mother Jaguar was responsible for their mother's death, and were avenging themselves on her for it. This would make their actions in killing her more understandable, and suggests that something may have been left out of the version I recorded.

${ }^{6}$ The sequence of events described in this paragraph was not clear to me, and may not be in the correct order.
${ }^{7}$ This was said despite the informant's having just finished telling me that the Mother Jaguar's skin had torn up the stakes and turned into an evil spirit.

${ }^{8}$ This may be a Conibo/Shipibo element in the myth, since - as indicated earlier the Amahuaca do not have the blowgun and the Conibo/Shipibo do.

${ }^{9}$ Another Conibo/Shipibo element, since traditionally the Amahuaca lacked any kind of watercraft.

${ }^{10}$ Obviously, this way of indicating successive intervals of time since the tapir had passed gives the narrator a chance to draw out this episode as long as he wishes. And here he seems to have gone to excessive lengths!

${ }^{11}$ The informant said something here about punishment that I did not understand.

${ }^{12}$ In one version of the myth - again, no doubt, a Conibo/Shipibo one - the spear is a pucuna, that is, a blowgun. The spear, however, is likewise not an Amahuaca weapon, belonging more to tribes of the northern part of the Peruvian Montaña or the Ecuadorian Oriente, as, for example, the Jívaro (Shuar).

${ }^{13}$ Here we have the familiar and widely distributed arrow chain myth motif, occurring in the mythology of both North and South America and, no doubt, in other parts of the world as well.

${ }^{14}$ Kapikuwi, in another context, was said by informants to be a constellation representing a one-legged man who, in mythological times, had lost his leg to a caiman, kapï.

\section{REFERENCES}

Carneiro, R. L. 1989. To the village of the Jaguars: The Master Myth of the Upper Xingú. Antropológica 72: 3-49.

Laraia, R. de B. 1967. O sol e a lua na mitologia Xinguana. Revista do Museu Paulista 12(n.s.):7-36.

Métraux, Alfred. 1946. Twin heroes in South American Mythology. Journal of American Folklore 59:114-123. 